\title{
MOBILIÁRIO URBANO: PROJETO DE UM BICICLETÁRIO
}

\author{
Gisele Reis Correa Saraiva, Mestra \\ Universidade Federal do Maranhão - UFMA \\ gisarco41@gmail.com \\ Paulo Vitor Goiabeira dos Santos, Graduando \\ Universidade CEUMA \\ pvsantos01@gmail.com
}

\begin{abstract}
Resumo: "Mobiliário urbano: projeto de um bicicletário", refere-se a uma pesquisa teórico e prática que tem por objetivo projetar um bicicletário, possibilitando acomodação adequada de bicicletas para usuários que transitam pelas cidades, colaborando assim com a melhoria do mobiliário e da mobilidade urbana. A falta desse equipamento urbano nos espaços públicos, a deficiência da mobilidade nas cidades fazem surgir a necessidade de um projeto que leve em consideração o usuário, o cenário urbano atual, a fim de abrigar e de servir adequadamente às bicicletas. Para fundamentação teórica traz-se considerações sobre mobilidade urbana e mobiliário urbano. Outros aspectos foram analisados, como os processos produtivos, as tecnologias e os materiais a serem empregados na elaboração do modelo do bicicletário. Todo o processo foi orientado por um modelo de desenvolvimento projetual embasado na metodologia de Löbach (2001), resultando em um projeto de bicicletário, que satisfaça a função de acomodação adequada de bicicletas de usuários que transitam pelas cidades, contribuindo com melhorias do mobiliário urbano, composição estética da paisagem das cidades e da mobilidade urbana.
\end{abstract}

Palavras-chave: Mobiliário urbano, bicicleta, mobilidade

\begin{abstract}
Urban furniture: Project of a bicycle parking, it's about a theoretical research and practical use with purpose of design a bicycle parking allow the correct accommodation of bicycles to people who uses this vehicle through the city, collaborating with the improvement of the urban furniture and urban mobility. Because of the scarce of this urban equipment on public spaces and the shortcoming of mobility on cities, it becomes necessary a design that cares with the usufructuary, with the present urban scenery to serve the bicycles properly. To theoretical foundation this report brings comments about urban mobility and urban furniture. Other aspects were analyses, just like the productive process, the technologies and the materials there will be used on the development of bicycle parking model. The whole process was guided by a design based on Löbach methodology (2001) resulting in a bicycle parking that satisfy the function of a properly accommodation to the users that that rides through
\end{abstract}


the cities, contributing with improvements for urban furniture, the city landscape esthetic composition and urban mobility too.

Key-words: Urban furniture, bicycle, mobility 